Article

\title{
The UK Government's Troubled Families Programme: Delivering Social Justice?
}

\author{
Stephen Crossley \\ Department of Social Work, Education and Community Wellbeing, Northumbria University, Newcastle upon Tyne, NE1 8ST, \\ UK; E-Mail: stephen.crossley@northumbria.ac.uk
}

Submitted: 31 March 2018 | Accepted: 10 July 2018 | Published: 28 September 2018

\begin{abstract}
This article examines and reviews the evidence surrounding the UK Government's Troubled Families Programme (TFP), a flagship social policy launched in 2011, following riots in towns and cities across England. The programme aims to work with over 500,000 'troubled families' by 2020, using a 'whole family' intervention. It has been beset by controversy and criticism since its inception, but it has been described by the government as 'promoting social justice'. Drawing on Nancy Fraser's work around recognition and redistribution, this article assesses the subjective aims and achievements of the TFP and locates this analysis in the wider objective conditions experienced by disadvantaged families in the UK at the current time.
\end{abstract}

\section{Keywords}

austerity; disadvantaged families; family intervention; government aid; poverty; social justice; troubled families

\section{Issue}

This article is part of the issue "Vulnerable and Disadvantaged Groups: On the Margins of the Welfare State?", edited by Inger Lise Skog Hansen and Tone Fløtten (Fafo Institute for Labour and Social Research, Norway).

(C) 2018 by the author; licensee Cogitatio (Lisbon, Portugal). This article is licensed under a Creative Commons Attribution 4.0 International License (CC BY).

\section{Introduction}

The UK Government's Troubled Families Programme (TFP) is a UK government programme that seeks to work with some of the most putatively 'troubled' families in England. ${ }^{1}$ Established in the aftermath of riots in towns and cities across England in 2011, the programme, now in its second phase, advocates an intensive 'family intervention' model to help 'turn around' the lives of 'troubled families' in the first phase, and help them to make 'significant and sustained progress', in the second phase. The 'persistent, assertive and challenging' family intervention approach is intended to replace multiple, uncoordinated interventions by specialist services, which work with individual family members but allegedly fail to see the family 'as a whole'. The TFP remains one of only two family programmes that receive funding from the UK government (Department for Communities and Local Government [DCLG], 2017, p. 1).
The programme, officially launched in December 2011, was one of the most high-profile social policies of the coalition government formed between the Conservative and Liberal Democrat parties following the 2010 General Election in the UK. Work to support individuals and families living profoundly troubled lives marked by multiple disadvantages' was placed at the centre of the coalitions' Social Justice Strategy (SJS). The strategy argues that 'the family is the first and most important building block in a child's life and any government serious about delivering Social Justice must seek to strengthen families' (HM Government, 2012, p. 15). The SJS also states that 'troubled families':

Are families whose lives are blighted by crime, worklessness, drug and alcohol dependency, low aspirations and educational failure. The chaotic lifestyles these families lead, without routines or boundaries, often destroy the life chances of the children who grow up in them.

\footnotetext{
${ }_{1}^{1}$ The programme does not operate in the devolved administrations of Scotland, Wales or Northern Ireland.
} 
According to the SJS, the government would attempt to 'halt the cycle of inter-generational disadvantage that can be seen in some families... where no-one is working or where there is a history of inter-generational worklessness' (HM Government, 2012, p. 43). Social justice, according to the government strategy, is variously 'about making society function better-providing the support and tools to help turn lives around' and 'about ensuring everybody can put a foot on the [social mobility] ladder' (HM Government, 2012, p. 4).

The most recent annual report on the TFP states that the programme is 'promoting social justice' (Ministry of Housing, Communities and Local Government [MHCLG], 2018, pp. 29-39) and notes that:

The Troubled Families Programme supports the government's wider efforts to promote social justice and has committed to increase the contribution the programme makes to tackling worklessness, whilst reducing parental conflict and problem debt.

The section on 'promoting social justice' once again fails to provide an adequate definition of what the government means by 'social justice', and focuses primarily on 'worklessness', 'parental conflict and problem debt' and 'health'. It includes examples and case studies of how local services are supporting families in these areas. In one paragraph (MHCLG, 2018, p. 34), workers helping families to apply for bankruptcy and to access food banks are examples of the programme's role in promoting of social justice:

Forty-six percent of keyworkers provide support to families at least weekly around debts and money. Keyworkers are also able to help by supporting families in prioritising bills and clearing debts, applying for bankruptcy, applying for welfare benefits and attending relevant meetings, or accessing food banks.

There have been a number of publications critiquing different aspects of the TFP since it was established (see, for example, Bond-Taylor, 2015; Crossley, 2016, 2018; Hayden \& Jenkins, 2014; Lambert \& Crossley, 2017; Wenham, 2017). The coalition government's problematic lack of engagement with 'traditional' theories of social justice has also been noted elsewhere (Crossley, 2017), but, to date, there has been no critical examination of the specific governmental claim that the TFP is 'promoting social justice'.

Wolff $(2008$, p. 18) has suggested that John Rawls' Theory of Justice indicates that the justness of any given society should be judged by its treatment of its worstoff and most marginalised members. Rawls' work on distributive justice is perhaps the most well-known example of the redistribution paradigm of social justice, which focuses primarily on the distribution of resources, assets and economic inequalities. Rawls $(1999$, p. 6) argues that 'the primary subject of justice is the basic structure of so- ciety, or more exactly, the way in which the major social institutions distribute fundamental rights and duties and determine the division of advantages from social cooperation'. He also argues that the positions that people are born into have undeniable and far-reaching implications for the rest of their lives.

His work has been critiqued for a lack of engagement with issues around recognition and, more latterly, representation (Fraser \& Honneth, 2003). Fraser's work on the injustice that occurs when individuals and groups, are denied equal social and political standing, aside from issues of distributive justice, is particularly useful when considering the government 'labelling' of a group of families who, have been held 'responsible for a large proportion of the problems in society' (Cameron, 2011a) by a Prime Minister, and who have been portrayed as 'the worst families' (Hellen, 2014) by Louise Casey, a former senior civil servant. The label of 'troubled families' emerged at a time when austerity measures and welfare reforms were portrayed as supporting 'hardworking families' and other 'taxpayers', thus creating 'a class of devalued persons...impeded from participating on a par with others in social life' (Fraser \& Honneth, 2003, p. 30). Fraser argues that when:

Institutionalized patterns of cultural value constitute some actors as inferior, excluded, wholly other, or simply indivisible, hence as less than full partners in social interaction, then we should speak of misrecognition and status subordination. (Fraser \& Honneth, 2003 , p. 29, original emphasis)

In Fraser's terms, 'justice requires social arrangements that permit all (adult) members of society to interact with one another as peers' (Fraser \& Honneth, 2003, p. 36). For this level of participatory parity to be achieved, Fraser states that the distribution of material resources should ensure that individuals are not prevented from participation by economic or material hardship, deprivation or exploitation. It is also necessary for institutions and institutionalized practices to treat all potential participants as equals and not subordinate parties or 'Others' (Lister, 2004, pp. 100-103). Fraser referred to these two requirements as the objective and intersubjective conditions required for participatory parity.

Constraints of space prevent a fuller discussion of social justice theories (and critiques of them), but this article, then, uses Fraser's theory of social justice to examine the TFP and the extent to which it can be said to delivering or promoting social justice. At a time of widespread structural reform in the UK, it is appropriate to interrogate to what, if any, extent, a key government policy that is central to this restructuring (Crossley, 2016) addresses issues of misrecognition and distributive injustice. The next section provides a fuller introduction to the TFP, before the attention turns to the empirical evidence surrounding the potential of intensive work with disadvantaged families in the UK to improve the intersubjective 
conditions of social justice. A discussion of the effects of austerity policies, welfare reforms and cuts to local services on disadvantaged families examines the role of the UK government in providing the objective conditions for social justice. A concluding discussion suggests that substantial work is required on both fronts if the intersubjective and objective conditions for marginalised and disadvantaged families are to improve, let alone for participatory parity to be achieved.

\section{The Troubled Families Programme}

In August 2011, riots took place in towns and cities across England, sparked by the police killing of Mark Duggan in Tottenham, London on 4 August. By 15 August, more than 3000 people had been arrested, with more than 1000 criminal charges issued in relation to the riots. Politicians and journalists were quick to blame an alleged criminal and amoral 'underclass' for the riots, even whilst the disturbances were ongoing and before any independent inquiry had been established. David Cameron, the then Prime Minister, stated that the riots were not sparked by concerns about racist and discriminatory policing and nor were they related to the programme of austerity measures undertaken by the coalition or the increasing levels of inequality in the UK. Instead, Cameron (2011b) argued that the riots were about behaviour, people showing indifference to right and wrong, people with a twisted moral code, people with a complete absence of self-restraint. They were about people with a twisted moral code.

Eschewing possible social, structural and economic explanations for the involvement of thousands of people in the riots, Cameron (2011b) instead focused on the role of parenting, arguing that it was necessary only to join the dots' to get 'a clear idea about why...young people were behaving so terribly':

Either there was no one at home, they didn't much care or they'd lost control. Families matter. I don't doubt that many of the rioters out last week have no father at home. Perhaps they come from one of the neighbourhoods where it's standard for children to have a mum and not a dad, where it's normal for young men to grow up without a male role model, looking to the streets for their father figures, filled up with rage and anger. So, if we want to have any hope of mending our broken society, family and parenting is where we've got to start.

Cameron promised to put 'rocket boosters' under attempts to work with the 'problem' or 'troubled families' 'that everyone in their neighbourhood knows and often avoids'. Four months later, a new government programme was announced which aimed to 'change completely the way government interacts with ['troubled families']; the way the state intervenes in their lives' (Cameron, 2011a). At the launch of the programme,
Cameron (2011a) stated that he wanted to be clear what he meant by 'troubled families':

Officialdom might call them 'families with multiple disadvantages'. Some in the press might call them 'neighbours from hell'. Whatever you call them, we've known for years that a relatively small number of families are the source of a large proportion of the problems in society. Drug addiction. Alcohol abuse. Crime. A culture of disruption and irresponsibility that cascades through generations.

'Troubled families' thus became the latest iteration of the 'underclass' thesis that has been a recurrent feature of British society since at least Victorian times (Welshman, 2013). At various times, for example, there have been concerns about a 'social residuum' (Himmelfarb, 1984), 'problem families' (Starkey, 2000), 'transmitted deprivation' (Welshman, 2012), 'the underclass' (Macnicol, 1987, 1999) and the 'socially excluded' (Levitas, 1998). The TFP became merely the most recent UK government attempt to control and change the behaviour of the 'undeserving poor'. It set out to work with and 'turn around' the lives of 120,000 'troubled families' by the end of the coalition government's term of office in May 2015. 'Troubled families' were initially defined as: those that were involved in crime and/or anti-social behaviour (ASB); with children excluded from school or with low attendance, with an adult on out-of-work benefits or; who cause 'high costs to the taxpayer' (DCLG, 2012, p. 9).

The TFP was to be based on a model of 'family intervention' that involves a single key worker who can resolve longstanding issues through a 'persistent, assertive and challenging' (DLCG, 2012, p. 6) approach and through greater co-ordination of existing services:

Family intervention workers are dedicated to the families and provide an antidote to the fragmented activity from many different agencies that usually surrounds a troubled family. They 'grip' the family, their problems and the surrounding agencies and are seen to be standing alongside the families, their difficulties and the process being put in place, which can lead to new approaches to dealing with long standing problems. (DCLG, 2012, p. 18)

The programme was established on a Payment-byResults (PbR) basis which would see local authorities receiving some initial funding when they started working with 'troubled families' in their area and further funding when certain behaviour criteria had been met. A reduction in crime and/or ASB and improvements in school attendance, or an adult moving into 'continuous employment and off out-of-work benefits' could trigger a PbR claim (but not both). The government claimed that such families had had their lives 'turned around' by the TFP. Other issues which might have been affecting the family, such as poverty, poor housing, ill health, substance 
misuse, domestic violence etc., were not recognised by the $\mathrm{PbR}$ system and were not taken into account in the government's presumption of a family's life having been 'turned around'.

A year into the programme, the 'massive expansion' of the TFP was announced. 400,000 more 'troubled families' were identified, using different criteria which now included domestic violence, ill health and 'children in need'. These new families would be worked with under a second phase of the programme, running from 2015-2020. The language of 'turning around' the lives of 'troubled families' was dropped and local authorities were now expected to be able to demonstrate families making 'significant and sustained progress' in order to trigger a PbR claim.

In June 2015, the government claimed that it had successfully 'turned around' the lives of $99 \%$ of the 'troubled families' that local authorities had worked with under the programme. The claims of near perfect success were immediately called into question (Crossley, 2015) and reports emerged that the independent evaluation of the TFP had been 'suppressed' (Cook, 2016) because it was unable to find any discernible impact attributable to the programme. Since these early controversies, the programme has operated with a much lower public profile in its second phase.

\section{The Misrecognition of 'Troubled Families'}

The TFP has been subjected to numerous critiques since its inception. At the launch of the programme, the government misused research which showed the number of families experiencing multiple disadvantages in the mid2000 s as 'evidence' of 120,000 'troubled families' who were the 'source of a large proportion of the problems in society' (Cameron, 2011a). Levitas (2012, p. 5) noted that because the 120,000 figure was taken from a survey carried out with a very small number of families 'anyone with any statistical sophistication will recognise it as spuriously accurate'. Levitas then turned to the label 'troubled families' which, she argued, 'discursively collapses "families with troubles" and "troublesome families", while simultaneously implying that they are dysfunctional as families'-a 'discursive strategy [that] is successful in feeding vindictive attitudes to the poor' (Levitas, 2012, p. 8). She suggested that the original research was not the problem, but the representation of it by the government was problematic and misleading:

If we interrogate the research behind the imputed existence of 120,000 troubled families, this turns out to be a factoid-something that takes the form of a fact, but is not. It is used to support policies that in no way follow from the research on which the figure is based. The problem is not the research itself, but its misuse.

The misuse or misrepresentation of research has continued throughout the development of the TFP. A survey which enabled Louise Casey to make the case for radical reform of public services turned out to have been invented (Crossley, 2018, pp. 150-151). 'Dipstick information gathering', undertaken without any ethical procedures being followed, was published in an official government document and was promoted by Casey giving numerous interviews to national newspapers (Ramesh, 2012). Data which highlighted that the majority of the 'troubled families' worked with in the early stages of the first phase of the programme were not involved with significant amounts of crime or antisocial behaviour was reported as proving that they were 'the worst families' (Hellen, 2014) with greater problems than originally anticipated. A Parliamentary Enquiry concluded that the DCLG had been 'evasive' in addressing their queries about the delayed publication of the evaluation, and that 'these delays and obfuscation have given a bad impression about the Department's willingness to be open' (House of Commons Committee of Public Accounts, 2016, p. 5).

The government eventually published the evaluation of the first phase of the programme in October 2016. There were a number of different streams to the evaluation, including a family survey, 'family monitoring data', families' experiences and outcomes, and an impact study. Much of the press coverage that followed the publication of the evaluation focused on the findings from the national impact study, and one paragraph in particular:

The key finding is that across a wide range of outcomes, covering the key headline objectives of the programme-employment, benefit receipt, school attendance, safeguarding and child welfare-we were unable to find consistent evidence that the TFP had any significant or systematic impact. That is to say, our analysis found no impact on these outcomes attributable to the programme. The vast majority of impact estimates were statistically insignificant, with a very small number of positive or negative results. These results are consistent with those found by the separate and independent impact analysis using survey data, which also found no significant or systemic impact on outcomes related to employment, job seeking, school attendance, or ASB. This gives us further confidence in the reliability of our results (Bewley, George, Rienzo, \& Portes, 2016, p. 20).

This focus on one aspect of the evaluation meant that other aspects of it did not receive as much scrutiny as they arguably deserved. The Family Monitoring Data report showed that the clear majority of 'troubled families' that local authorities worked with weren't actually that troublesome or anti-social (see also Crossley, 2015). The Family Survey Data report (Purdon \& Bryson, 2016) collected data from the families themselves, and provided support to the national impact study findings that no impact could be attributable to the programme. The report, based on responses from 495 families who had been on the programme for nine months and a comparison group of 314 families who had just started on the programme, 
was unable to find any impact attributable from the programme, based on responses from families:

We found very little evidence that the Troubled Families Programme significantly affected the outcomes of families around nine months after starting the programme. The statistically significant improvements we did identify relate to the perceptions of main carer respondents in the Troubled Families group about how they were coping financially, and more generally about how they felt they were faring, and their expectations for the future. There were no positive (or negative) impacts identified for housing, employment and jobseeking, anti-social behaviour and crime, school behaviour and attendance, health, drug or alcohol use, family dynamics or well-being. (Purdon \& Bryson, 2016, p. 24)

The government reported that the programme had 'turned around' $99 \%$ of the 'troubled families' it set out to work with. The evaluation did not report if any families interviewed or surveyed thought that their lives had been 'turned around' by their involvement in the TFP. At the same time, families' household income levels and/or the extent of any material deprivation were not formerly assessed or reported on during the first phase of the programme.

The TFP was not the only government policy targeting disadvantaged families. When David Cameron was Prime Minister he made several speeches about the importance of families, claiming that they are 'the building blocks of a strong, cohesive society' (Cameron, 2010) and that 'whatever the social issue we want to graspthe answer should always begin with family' (Cameron, 2014). In a speech on improving children's life chances, Cameron (2016) claimed that 'families are the best antipoverty measure ever invented...[t]hey are a welfare, education and counselling system all wrapped up into one'.

In the coalition government's first child poverty strategy (HM Government, 2011), Sure Start children's centres were re-positioned as being services that 'targeted' the 'most disadvantaged families'. The same document linked the recruitment of an extra 4,200 health visitors to other work focusing on the 'most disadvantaged families', or those with 'multiple problems' (HM Government, 2011 , p. 4). The introduction of the Family Nurse Partnership (FNP) in 2007 was designed to support young mothers and pregnant women in their parenting through a programme of intensive home visits. Building on a model imported from the United States, it offered a 'psychoeducational approach and a focus on positive behaviour change' (Family Nurse Partnership [FNP], n.d.). The FNP website alludes to the 'underclass' thesis (Welshman, 2013) stating that it is a 'preventive programme [that] has the potential to transform the life chances of the most disadvantaged children and families in our society, helping to improve social mobility and break the cycle of intergenerational disadvantage' (FNP, n.d., emphasis added).
There are parallels between the FNP and the TFP, most notably the emphasis on intensive work carried out during frequent visits to the family home, and a focus on mothers over other family members. The official evaluation of the FNP found that the programme was 'no more effective than routinely available healthcare' in improving any of the primary outcomes of the programme, which included reducing smoking in pregnancy, increasing birth weight and reducing rates of emergency attendance or hospital admission for any reason (Robling, 2015, p. 10). The researchers concluded that there was 'little advantage' to be gained from adding the FNP to existing service provision for young mothers.

According to the first TFP annual report, the TFP and the FNP are the 'only two family programmes with major funding from central government' (DCLG, 2017, p. 1). Unfortunately, there is no substantial independent evidence that either programme is meeting its stated aims. This should not, however, be particularly surprising. Policies and programmes which locate the source of families' problems within the home, or 'the family' whilst ignoring the wider social, political and cultural determinants of family life are unlikely to be able to affect significant change across families experiencing a wide range of disadvantages. Different approaches, or foci, of such programmes fail to adequately interrogate the sources of many of the problems faced by disadvantaged families. The TFP, the family intervention model it is based on, and other forms of recent state intervention in the lives of families experiencing 'troubles' or 'multiple disadvantages' are not, however, designed to address structural issues or distributive injustices such as poverty and inequality. The 'orgy of family-blaming' (Gillies \& Edwards, 2012, p. 432) that followed the riots in 2011 and the primary focus on 'interventions' in family life to address a range of 'social problems' leaves no room for the empowerment of marginalised families, or even the treatment of them as equals. The programme, and others like it, is based on the misrecognition of the origins of poor families' problems and challenges, and does not afford them participatory parity of any kind.

\section{Redistribution Policies for Disadvantaged Families}

At the same time that the UK government was claiming it had 'turned around' the lives of 120,000 of the most 'troubled families' in England, and thus addressing the intersubjective conditions required for participatory parity, it was also embarking on one of the biggest programmes of 'welfare reform' ever seen in the UK. Both of the parties that formed the coalition government agreed on the need for austerity measures to help the UK economy to recover following the banking crises of 2007-2008. The defining feature of their political programme was the insistence on the need to reduce public spending. The result was a plan which would see the UK 'have the lowest share of public spending among major capitalist economies, including the USA' with 'the welfare 
state...under the most severe and sustained attack it has faced' (Taylor-Gooby, 2013).

The 'ideological re-working' of austerity (Clarke \& Newman, 2012, p. 300), from a temporary but necessary economic response to a financial crisis to a longterm political response to an allegedly bloated and overgenerous welfare state, saw intense public scrutiny fall upon people claiming out-of-work benefits. Labels such as 'shirkers', 'skivers' and 'troubled families' were used to justify cuts in public spending and other structural adjustments to the welfare state, and also served to deflect attention away from malpractice and mismanagement in the financial sector.

The early stages of the coalition government saw a number of changes and 'reforms' to the financial support offered by the state to disadvantaged groups. Some benefits, such as Child Benefit, and some elements of tax credits, were frozen for three years while others were limited to increases of just $1 \%$ for certain periods of time. A 'benefit cap' was introduced in 2013, and then reduced in 2016, limiting the total amount of benefits that any single household could claim. A spare room subsidy, popularly known as the 'bedroom tax' was also introduced for social housing tenants who were deemed to be 'underoccupying' their property. Some benefits, such as the Employment Maintenance Allowance and the Health in Pregnancy Grant, were cut completely. The campaigning charity Child Poverty Action Group estimated that a baby born in April 2011 would have been around $f 1500$ worse off than one born in April 2010 as a result of the early Coalition government welfare reforms (CPAG, 2011). The eligibility criteria for disability and incapacity benefits have been made more restrictive and some elements made time-limited and means tested (De Agostini, Hills, \& Sutherland, 2014, p. 11). In October 2016, an inquiry conducted by the United Nations Committee on the Rights of Persons with Disabilities (UNCRPD) into the impact of welfare reforms on disabled people concluded that there was reliable evidence that the threshold of grave or systematic violations of the rights of persons with disabilities' had been met (United Nations Committee on the Rights of Persons with Disabilities [UNCRPD], 2016, p. 20).

Welfare reforms have thus disproportionately impacted on poor families with children, with disabled families also being adversely affected in comparison with other groups. The most recent set of official child poverty figures released by the UK government showed that more than 100,000 extra children were living in poverty in the UK compared to the previous year. It is the third consecutive year-on-year increase and the percentage of children living in poverty is predicted to increase from $29.7 \%$ to $36.6 \%$ in $2021-2022$, according to analysis undertaken by the Institute for Fiscal Studies (Hood \& Waters, 2017, p. 15). Foodbank usage in the UK has increased dramatically in the years since the coalition government took office, and many people that use foodbanks do so because of benefit changes and delays
(Garthwaite, 2016; Loopstra \& Lalor, 2017). The rolling out of Universal Credit, the government's flagship social policy reform, is estimated to strip away $f 5.5$ billion of benefit entitlements from poorer households (Hood \& Waters, 2017, p. 23). Analysts have argued that transitioning to Universal Credit will involve 'significant income losses' (Hood \& Waters, 2017, p. 15) for poor households with three or more children as a result of the limiting of the child element of universal credit to two children.

In addition to these 'reforms' which have seen some benefits withdrawn entirely, the levels of others reduced, and new assessment procedures and changes to eligibility criteria, there has been a significant increase in the numbers of people penalised and sanctioned for not meeting certain conditions attached to unemployment and 'job-seeking' related benefits. Potential sanctions have traditionally played a limited role in the administration of social security benefits but, in recent years, the rate and severity of sanctions has increased substantially. In a series of publications and briefings drawing on historical documents and DWP statistics David Webster has highlighted these changes. Webster (2015) has referred to the sanctions as 'an amateurish, secret penal system which is more severe than the mainstream judicial system, but lacks its safeguards'. He documented that more people were sanctioned through the benefits system than received fines through the criminal justice and court system (Webster, 2015). He also highlighted that 'sanctioned benefit claimants are treated much worse than those fined in the courts' (Webster, 2015) and points out that sanctions are generally applied to poor people and they tend to result in almost total loss of benefit income for a period of at least two weeks, despite a system of 'hardship payments'. Webster suggests that sanctions push people off benefits, but not necessarily into employment of any kind, least of all good quality, and secure work. He goes on to expound some of the other consequences of sanctions:

Sanctions undermine physical and mental health, cause hardship for family and friends, damage relationships, create homelessness and drive people to Food Banks and payday lenders, and to crime. They also often make it harder to look for work. Taking these negatives into account, they cannot be justified.

At the same time that sanctions have been preventing people from claiming the benefits they are legitimately entitled to, the increasing stigmatisation surrounding benefits claimants and the continuing complexity of the system means that many people do not claim the benefits that they are entitled to receive. Research around the increased stigmatisation associated with claiming benefits reported that 'quantitative and qualitative evidence suggests that stigma is playing a role in explaining nontake-up of benefits and tax credits' with around $25 \%$ of respondents to a survey highlighting stigma as a reason for delaying or not claiming benefits (Baumberg, Bell, \& 
Gaffney, 2012, p. 3). Official government statistics (which the 'troubled families' turned around figures are not) suggest that around $40 \%$ of people entitled to JSA do not claim the benefit (DWP, 2017, p. 1). In total, the government estimated that over $£ 12$ billion of benefits remained unclaimed in 2015-2016. Thus, the stigmatisation and misrecognition of people in receipt of benefits as 'scroungers' and 'skivers' adds to and strengthens the distributive injustices they experience.

A number of reports by academics and independent researchers have highlighted the regressive nature of many of the welfare reforms undertaken since 2010 (Beatty \& Fothergill, 2013, 2016; De Agostini et al., 2014; Portes \& Reed, 2018) and the impact of cuts to local government and the reduction is services that they offer (Hastings, Bailey, Bramley, Gannon, \& Watkins, 2015). Economic geographers noted that ' 83 per cent of the loss from the post-2015 reforms $-£ 10.7 \mathrm{bn}$ a year by 2020-21-can be expected to fall on families with dependent children' (Beatty \& Fothergill, 2016, p. 3). More recently, a report for the Equality and Human Rights Commission has demonstrated that 'the largest impacts are felt by those with lower incomes' (Portes \& Reed, 2018 , p. 15). The analysis also noted that the changes have a disproportionately negative impact on several protected groups, including disabled people, certain ethnic groups, and women' and that 'lone parents in the bottom quintile (bottom fifth) of the household income distribution lose around 25 per cent of their net income, or one pound in every four, on average' (Portes \& Reed, 2018, p. 15).

Given the analysis and statistics outlined above, it is difficult to construct an argument that the government is improving the objective conditions for 'troubled families' to be treated as equals and for issues of social injustice to be addressed. The government's welfare reforms have disproportionately affected disadvantaged groups, leading to larger numbers of children living in poverty and more people needing to rely on emergency food packages provided by foodbanks. It is poor families with children, the supposed 'beneficiaries' of the TFP, that have been hit hardest by these reforms.

\section{Conclusion}

Fraser was clear that social justice could not be achieved through redistribution or recognition alone. Instead, she proposed 'a "perspectival dualist" analysis that casts the two categories as co-fundamental and mutually irreducible dimensions of justice' (Fraser \& Honneth, 2003, p. 3). Examination of the effects of the TFP and similar policies being pursued in the UK at the current time highlight how the conditions of redistribution and recognition are linked. Poor and disadvantaged families experiencing material deprivation and economic hardship have been portrayed as criminal, anti-social and a burden on the 'taxpayer'. They have frequently been contrasted to more respectable 'hard-working families'. When fam- ilies' resources become so low or precarious that they have to access food banks, they experience the stigma and shame that is attached to relying on donations of food from strangers at a time when people who are eligible for out-of-work or disabled benefits are portrayed as 'scroungers' and 'benefits cheats' by sections of the media and some politicians (Garthwaite, 2016).

Many families experience challenges or troubles that they require support with. Some disadvantaged families experience more problems than others, often at the same time, and for varying periods of time. In such cases, it is absolutely right that the state provides support to such families. These families do not need to be given an official label like 'troubled families', and nor do they need to be linked to a wide range of disparate social problems. The support available to such families does not need to be couched as a targeted 'persistent, assertive and challenging' intervention, and nor does it need to portray families as the architects of their own circumstances. As Lister (1996, p. 11) noted when discussing Charles Murray's writing on the 'underclass', 'the use of stigmatising labels is likely to lead to stigmatising policies', and the same is certainly true of the TFP. Support available to families experiencing multiple 'troubles' should come through universal programmes and in the form of an adequate income. It is perfectly possible to provide supportive services (as opposed to 'intensive interventions') to families as and when they need them and in a nonstigmatising way, at the same time as ensuring they have an adequate income which prevents them from being excluded from services, customs and patterns of activities that others take for granted. Delivering socially just support to marginalised families cannot be a case of either/or, as Fraser points out. It was not that long ago in the UK that Sure Start centres were being opened at the same time that tax credits and benefits for families with children were being extended (although problematic targeted policies co-existed alongside more universal provision even then). All that is required for a similar situation to (re)emerge is the political imagination and will to implement such services and policies.

The TFP, then, despite grand claims about having 'turned around' the lives of 'troubled families', helping many more make 'significant and sustained progress', and of 'promoting social justice', is found wanting when it is examined using Fraser's two-dimensional conception of social justice. In the UK at the current time, the government appears to be extending injustice, through the misrecognition of the source of 'troubled families', and the inequitable distribution of the effects of its austerity policies.

\section{Acknowledgements}

The author would like to acknowledge the emotional and intellectual support of Daisy Crossley, Sam Crossley and Harriet Menter. 


\section{Conflict of Interests}

The author declares no conflict of interests.

\section{References}

Baumberg, B., Bell, K., \& Gaffney, D. (2012). Benefits stigma in Britain. London: Turn2Us. Retrieved from wwwturn2us-2938.cdn.hybridcloudspan.com/ T2UWebsite/media/Documents/Benefits-Stigma-inBritain.pdf

Beatty, C., \& Fothergill, S. (2013). Hitting the poorest places hardest: The local and regional impact of welfare reform. Sheffield: Sheffield Hallam University, Centre for Regional Economic Social Research.

Beatty, C., \& Fothergill, S. (2016). The uneven impact of welfare reform: The financial losses to places and people. Sheffield: Sheffield Hallam University, Centre for Regional Economic Social Research.

Bewley, H., George, A., Rienzo, C., \& Portes, J. (2016). National evaluation of the troubled families programme: National impact study report findings from the analysis of national administrative data and local data on programme participation. London: Ministry of Housing, Communities and Local Government.

Bond-Taylor, S. (2015). Dimensions of family empowerment in work with so-called 'troubled' families. Social Policy and Society, 14(3), 371-384.

Cameron, D. (2010). Speech on families and relationships: A transcript of a speech given by Prime Minister David Cameron to Relate in Leeds about families on 10 December 2010. Gov.uk. Retrieved from www. gov.uk/government/speeches/speech-on-familiesand-relationships

Cameron, D. (2011a). Troubled families speech: David Cameron's speech on plans to improve services for troubled families. Gov.uk. Retrieved from www.gov. uk/government/speeches/troubled-families-speech

Cameron, D. (2011b). PM's speech on the fightback after the riots. Gov.uk. Retrieved from www.gov.uk/ government/speeches/pms-speech-on-the-fightback -after-the-riots

Cameron, D. (2014). Speech at the Relationships Alliance Summit. Gov.uk. Retrieved from www.gov.uk/ government/speeches/david-cameron-on-families

Cameron, D. (2016). Prime Minister's speech on life chances. Gov.uk. Retrieved from www.gov.uk/ government/speeches/prime-ministers-speech-onlife-chances

Clarke, J., \& Newman, J. (2012). The alchemy of austerity. Critical Social Policy, 32(3), 299-319.

Cook, C. (2016). Troubled families report 'suppressed'. $B B C$ News online. Retrieved from www.bbc.co.uk/ news/uk-politics-37010486

CPAG. (2011). Complacent budget puts child poverty promise at risk. Child Poverty Action Group. Retrieved from www.cpag.org.uk/content/complacent-budgetputs-child-poverty-promise-risk-1
Crossley, S. (2015). The troubled families programme: The perfect social policy? (Briefing 13/2015). London: Centre for Crime and Justice Studies. Retrieved from www.crimeandjustice.org.uk/sites/crimeandjustice. org.uk/files/The\%20Troubled\%20Families\%20Progra mme\%2C\%20Nov\%202015.pdf

Crossley, S. (2016). 'Realising the (troubled family)', 'crafting the neoliberal state'. Families, Relationship and Societies, 5(2), 263-279.

Crossley, S. (2017). The 'official' social justice. Journal of Poverty and Social Justice, 25(1), 21-33.

Crossley, S. (2018). Troublemakers: The construction of 'troubled families' as a social problem. Bristol: Policy Press.

Department for Communities and Local Government. (2012). Working with troubled families. London: Ministry of Housing, Communities and Local Government.

Department for Communities and Local Government. (2017). Supporting disadvantaged families. Troubled families programme 2015 to 2020: Progress so far. London: Ministry of Housing, Communities and Local Government.

De Agostini, P., Hills, J., \& Sutherland, S. (2014). Were we really all in it together? The distributional effects of the UK coalition government's tax-benefit policy changes (Working Paper 10). London: Centre for Analysis of Social Exclusion, LSE.

DWP. (2017). Income-related benefits: Estimates of takeup. Data for financial year 2014/15. London: Department for Work and Pensions.

Family Nurse Partnership. (n.d.). About us. Family Nurse Partnership. Retrieved from fnp.nhs.uk/about-us

Fraser, N., \& Honneth, A. (2003). Redistribution or recognition? A political-philosophical exchange. London: Verso.

Garthwaite, K. (2016). Hunger pains: Life inside foodbank Britain. Bristol: Policy Press.

Gillies, V., \& Edwards, R. (2012). Farewell to family? A reply. Families, Relationships and Societies, 1(3), 431-434.

Hastings, A., Bailey, N., Bramley, G., Gannon, M., \& Watkins, D. (2015). The cost of the cuts: The impact on local government and poorer communities. York: Joseph Rowntree Foundation.

Hayden, C., \& Jenkins, G. (2014). 'Troubled families' programme in England: 'Wicked problems' and policybased evidence. Policy Studies, 35(6), 631-649.

Hellen, N. (2014). Rise of new underclass costs $£ 30 \mathrm{bn}$. The Sunday Times. Retrieved from www.thetimes.co. uk/article/rise-of-new-underclass-costs-pound30bnrn25xwwk8rt

Himmelfarb, G. (1984). The idea of poverty: England in the early Industrial Age. New York, NY: Knopf.

HM Government. (2011). A new approach to child poverty: Tackling the causes of disadvantage and transforming families' lives. London: The Stationery Office. 
HM Government. (2012). Social justice: Transforming lives. London: The Stationery Office.

Hood, A., \& Waters, T. (2017). Living standards, poverty and inequality in the UK: 2017-18 to 2021-22. London: Institute for Fiscal Studies.

House of Commons Committee of Public Accounts. (2016). Troubled families: Progress review (Report 33 HC 711). Retrieved from www.publications. parliament.uk/pa/cm201617/cmselect/cmpubacc/ 711/711.pdf

Lambert, M., \& Crossley, S. (2017). 'Getting with the (troubled families) programme': A review. Social Policy and Society, 16(1), 87-97.

Levitas, R. (1998). The Inclusive Society? Social exclusion and new labour. Houndmills: Macmillan.

Levitas, R. (2012). There may be 'trouble' ahead: What we know about those 120,000 'troubled families' (PSE Working Paper 3). Swindon: Economic and Social Research Council. Retrieved from www.poverty. ac.uk/policy-response-working-paper-families-socialjustice-life-chances-children-parenting-uk-government

Lister, R. (Ed.). (1996). Charles Murray and the underclass: The developing debate. London: IEA.

Lister, R. (2004). Poverty. Cambridge: Polity.

Loopstra, R., \& Lalor, D. (2017). Financial insecurity, food insecurity, and disability: The profile of people receiving emergency food assistance from The Trussell Trust Foodbank Network in Britain. Salisbury: The Trussell Trust.

Macnicol, J. (1987). In pursuit of the underclass. Journal of Social Policy, 16(3), 293-318.

Macnicol, J. (1999). From 'problem family' to 'underclass' 1945-95. In H. Fawcett \& R. Lowe (Eds.), Welfare policy in Britain: The road from 1945 (pp. 69-93). Basingstoke: Macmillan.

Ministry of Housing, Communities and Local Government. (2018). Supporting disadvantaged families: Annual report of the troubled families programme 2017-18. London: The Stationery Office.

Portes, J., \& Reed, H. (2018). The cumulative impact of tax and welfare reforms. Manchester: Equality and Human Rights Commission.

Purdon, S., \& Bryson, C. (2016). Evaluation of the troubled families programme technical report: Impact evaluation using survey data. London: Ministry of Housing, Communities \& Local Government.

Ramesh, R. (2012). Troubled families tsar Louise Casey criticised over research. The Guardian. Retrieved from www.theguardian.com/society/2012/oct/24/ families-tsar-louise-casey-criticised

Rawls, J. (1999). A theory of justice (Revised ed.). Oxford: Oxford University Press.

Robling, M. (2015). The building blocks trial (Executive summary October 2015). Cardiff: Centre for Trials Research, Cardiff University. Retrieved from www.cardiff.ac.uk/_data/assets/pdf_file/0006/500 649/Building-Blocks-Executive-Summary-Report.pdf

Starkey, P. (2000). The feckless mother: Women, poverty and social workers in wartime and post-war England. Women's History Review, 9(3), 539-557.

Taylor-Gooby, P. (2013). The double crisis of the welfare state and what we can do about it. Basingstoke: Palgrave Macmillan.

United Nations Committee on the Rights of Persons with Disabilities. (2016). Inquiry concerning the United Kingdom of Great Britain and Northern Ireland carried out by the Committee under article 6 of the Optional Protocol to the Convention: Report of the Committee. Retrieved from www.ohchr.org/EN/ HRBodies/CRPD/Pages/InquiryProcedure.aspx

Webster, D. (2015). Benefit sanctions: Britain's secret penal system. Crime and Justice. Retrieved from www. crimeandjustice.org.uk/resources/benefit-sanctionsbritains-secret-penal-system

Welshman, J. (2012). From transmitted deprivation to social exclusion: Policy, poverty and parenting. Bristol: Policy Press.

Welshman, J. (2013). Underclass: A history of the excluded (2nd ed.). London: Hambledon/Continuum.

Wenham, A. (2017). Struggles and silences: Young people and the 'troubled families programme'. Social Policy and Society, 16(1), 143-153.

Wolff, J. (2008). Social justice and public policy: A view from political philosophy. In G. Craig, T. Burchardt, \& D. Gordon (Eds.), Social justice and public policy: Seeking fairness in diverse societies (pp. 17-32). Bristol: Policy Press.

\section{About the Author}

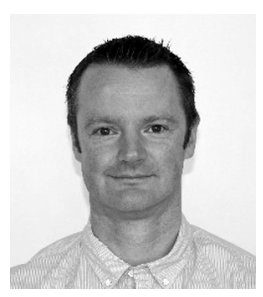

Stephen Crossley is a Senior Lecturer at Northumbria University. He completed his PhD on the Troubled Families Programme at the University of Durham. Prior to entering academia, he worked with young people and community groups across the North East of England in a variety of roles. His second book, Troublemakers: The Construction of 'Troubled Families' as a Social Problem, was published by Policy Press in April 2017. 